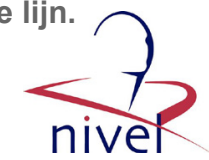

\begin{tabular}{|l|l|}
\hline $\begin{array}{l}\text { Postprint } \\
\text { Version }\end{array}$ & 1.0 \\
\hline Journal website & $\underline{\text { https://mijn.bsl.nl/morbiditeit-in-de-huisartsenpraktijk-nivel-zorgregistraties- }}$ \\
\hline Pubmed link & $\underline{\text { eers/6638092 }}$ \\
\hline DOI & $10.1007 / \mathrm{s} 12508-015-0114-7$ \\
\hline
\end{tabular}

This is a NIVEL certified Post Print, more info at http://www.nivel.eu

\title{
Morbiditeit in de huisartsenpraktijk: NIVEL Zorgregistraties eerste lijn
}

\author{
MARK NIELEN, ROBERT VERHEIJ \\ NIVEL
}

\begin{abstract}
SAMENVATTING
Huisartsen hebben een volledig beeld van de gezondheid van de Nederlandse bevolking. Bijna iedereen staat immers bij een huisarts ingeschreven en de huisarts is als poortwachter de eerste zorgprofessional waarmee contact wordt gezocht bij een medisch probleem. Het NIVEL gebruikt gegevens die huisartsen routinematig in hun elektronische patiëntendossiers vastleggen om landelijke morbiditeitscijfers te berekenen. Dit is echter nog niet zo eenvoudig, aangezien deze gegevens voor een ander doel worden vastgelegd.
\end{abstract}

\section{NIVEL ZORGREGISTRATIES EERSTE LIJN}

Elektronische patiëntendossiers van huisartsen zijn een zeer waardevolle gegevensbron voor wetenschappelijk onderzoek. Medische dossiers bevatten onder meer informatie over gestelde diagnoses, verrichtingen, voorgeschreven geneesmiddelen en meetwaarden. NIVEL Zorgregistraties verzamelt deze gegevens van meer dan anderhalf miljoen Nederlanders. 1 De vastgelegde diagnoses vormen de basis voor morbiditeitsschattingen die jaarlijks op de website van NIVEL Zorgregistraties worden gepubliceerd. 2 Afgelopen jaren heeft het NIVEL in samenwerking met het RIVM, het Nederlands Huisartsen Genootschap (NHG) en de Universiteit Nijmegen een methode ontwikkeld om door de huisarts geregistreerde gegevens te bewerken om te komen tot valide incidenties en prevalenties van gezondheidsklachten.

\section{VAN ZORG-EPISODE NAAR ZIEKTE-EPISODE}

Huisartsen registreren gezondheidsproblemen in zogenaamde zorgepisodes, gedefinieerd als 'de periode tussen het eerste en laatste contact van een patiënt voor een bepaald gezondheidsprobleem'. Voor morbiditeitsschattingen is het echter van belang om te weten wat de periode is tussen het stellen van de diagnose en het moment dat de patiënt weer beter is, oftewel een ziekte-episode. De huisarts wordt echter zelden door een patiënt op de hoogte gesteld wanneer een klacht over is. Om toch te komen tot eenduidige ziekte-episodes op basis van geregistreerde zorgepisodes, moeten er daarom aannames gedaan worden over hoe lang een 
aandoening nog duurt na het laatste contact met de huisarts op basis waarvan de stopdatum van de ziekte-episode geschat kan worden. Ook moet er rekening gehouden worden met de manieren waarop huisartsen informatie registreren in zorgepisodes. Vanuit het oogpunt van de huisarts kan het logisch zijn om bijvoorbeeld alle contacten voor een urineweginfectie in dezelfde zorgepisode te registreren als een patiënt jaarlijks meerdere malen last heeft van een urineweginfectie. Voor goede morbiditeitsschattingen is het juist van belang om iedere urineweginfectie mee te kunnen tellen en dus de zorgepisode 'op te knippen' in meerdere ziekte-episodes.

\section{HET CONSTRUEREN VAN ZIEKTE-EPISODES}

Daarom is er een algoritme ontwikkeld om op basis van zorgepisodes ziekte-episodes te construeren. Alle door de huisarts gestelde aandoeningen zijn op basis van de geschatte ziekteduur onderverdeeld in chronische en niet-chronische aandoeningen. Aan alle niet-chronische aandoeningen is een contactvrije periode toegekend, waarna de aandoening als genezen wordt beschouwd en de ziekte-episode wordt afgesloten. Bij chronische aandoeningen geldt de aanname 'eens ziek is altijd ziek'. Met deze methode wordt het mogelijk om met gegevens die routinematig in de huisartsenzorg worden vastgelegd, incidenties en prevalenties van gezondheidsklachten te berekenen. Zo maken we niet alleen optimaal gebruik van al beschikbare gegevens van een hele grote groep mensen, maar kan er op een relatief eenvoudige en goedkope manier een representatief beeld geschetst worden van de gezondheid van de Nederlandse bevolking.

\section{LITERATUUR}

1. http://www.nivel.nl/NZR/zorgregistraties-eerstelijn

2. http://www.nivel.nl/NZR/inci 